\title{
Zastosowanie badań nieniszczących w budowie i eksploatacji pojazdów samochodowych
}

\author{
Application of non-destructive testing in construction \\ and operation of motor vehicles
}

\section{Streszczenie}

W referacie zaprezentowano zastosowania metod badań nieniszczących w obszarze produkcji i eksploatacji pojazdów samochodowych. Skupiono się na badaniu połączeń zgrzewanych, ocenie jakości połączeń klejonych na karoserii pojazdu, monitorowaniu kinetyki tworzenia i degradacji połączenia szpachlówki ze stalowym podłożem oraz na ocenie grubości powłoki lakierniczej pojazdu. Przedstawione zagadnienia wsparto wybranymi wynikami badań własnych autorów.

Słowa kluczowe: badania nieniszczące; pojazdy samochodowe; połączenia adhezyjne

\section{Abstract}

In the paper some use of non-destructive testing methods in the area of production and operation of motor vehicles are presented. The focus is on the study of welded joints, on assessment of the quality of glued joints on the vehicle body, on monitoring the kinetics of formation and degradation of bonds of car putty and steel substrate, and on evaluation the thickness of the lacquer coating on the vehicle. The issues were supported by selected results of the authors' own investigations.

Keywords: non-destructive testing; motor vehicles; adhesive joints

\section{Wstęp}

Metody badań nieniszczących pozwalają na rozwiązanie wielu problemów technologicznych i eksploatacyjnych z obszaru budowy i eksploatacji pojazdów samochodowych. Wpisują się one w kształtowanie pewności, wiarygodności i bezpieczeństwa pojazdów samochodowych, poprzez kontrolę jakości w procesie wytwarzania i diagnostykę na etapie eksploatacji węzłów pojazdu samochodowego, odpowiedzialnych za niezawodne funkcjonowanie i bezpieczeństwo pojazdów. Poniżej, zaprezentowano wybrane przykłady ich zastosowania podczas wytwarzania elementów pojazdów, jako metody kontroli między- lub pooperacyjnej oraz w eksploatacji, zwłaszcza w operacjach naprawy, regeneracji i weryfikacji stanu fizycznego części lub węzłów samochodu.

Celem pracy jest prezentacja wybranych autorskich zastosowań metod badań nieniszczących, umożliwiających zwiększenie pewności funkcjonowania zespołów pojazdu samochodowego i - poprzez to - rzutujących na trwałości i bezpieczeństwo całego pojazdu w ruchu drogowym.

\section{Ultradźwiękowe badania zgrzein punktowych}

Zgrzewanie punktowe znajduje szerokie zastosowanie w budowie pojazdów samochodowych. Wykonanie zgrzeiny wysokiej jakości jest istotne z punktu widzenia sztywności karoserii, szczególnie ważne w warunkach wypadku drogowego, w czasie którego konstrukcja ma ochronić pasażerów. Dlatego połączenia zgrzewane punktowo są poddawane kontroli nieniszczącej, np. z zastosowaniem metody ultradźwiękowej. Metoda ultradźwiękowa pozwala na wykrywanie połączeń niskiej jakości. Do najczęściej występujących wad w połączeniach zgrzewanych punktowo zalicza się zbyt małe oczko zgrzeiny, przyklejenie, połączenie luźne oraz zmiany struktury stali w miejscu zgrzeiny wskutek zbyt

Tablica I. Badania ultradźwiękowe połączeń zgrzewnych Table I. Ultrasonic testing of welded joints

\begin{tabular}{|c|c|c|}
\hline $\begin{array}{c}\text { Widok połączenia } \\
\text { zgrzewanego }\end{array}$ & $\begin{array}{c}\text { Charakterystyczne } \\
\text { układy impulsów }\end{array}$ & Stan połączenia \\
\hline & &
\end{tabular}

Dr hab. inż. Marian Jósko, prof. nadzw.; dr inż. Jakub Kowalczyk; dr inż. Ryszard Mańczak; dr inż. Dariusz Ulbrich - Politechnika.

Autor korespondencyjny/Corresponding author. dariusz.ulbrich@put.poznan.pl 


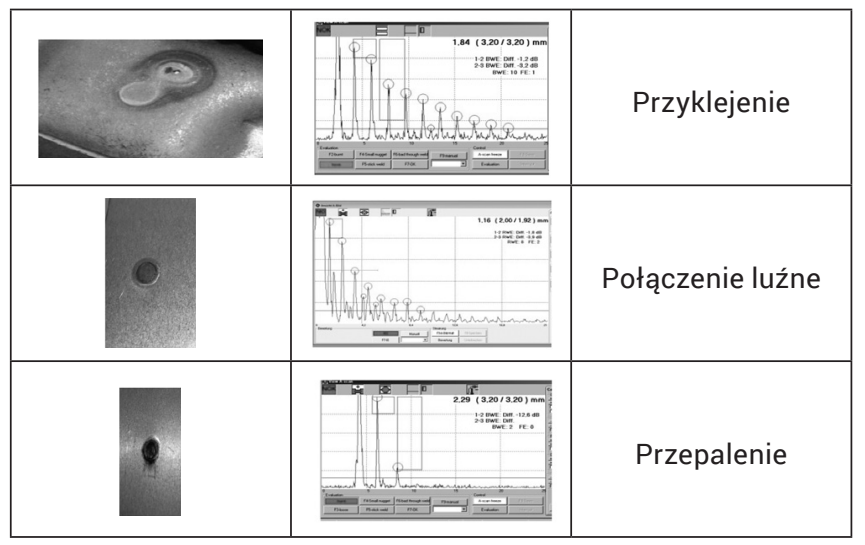

dużego prądu zgrzewania (tzw. przepalenie). W tablicy I przedstawiono przykłady wad spotykanych w praktyce produkcyjnej oraz obrazy impulsów ultradźwiękowej fali podłużnej, propagującej w obszarze połączenia dla poszczególnych przypadków, uzyskane na podstawie rezultatów własnych prac badawczych.

Technika ultradźwiękowej kontroli połączeń zgrzewanych jest wykorzystywana w dużych zakładach produkcyjnych (Volkswagen, Opel). Badania w takich firmach są prowadzone wg własnych procedur, które stanowią wewnętrzne dokumenty i nie są powszechnie dostępne.

\section{Zastosowanie metody ultradźwiękowej do oceny połączeń klejowych karoserii samochodu}

W ostatnich latach zauważalny jest wzrost zastosowania połączeń klejowych w procesie budowy nadwozi pojazdów samochodowych, które stopniowo wypierają klasyczne metody łączenia. Wykorzystuje się nie tylko kleje uszczelniające lub wygłuszające (tłumiące drgania), ale również tzw. kleje strukturalne, których zadaniem jest przenoszenie obciążeń, występujących podczas eksploatacji pojazdu. Mimo, że technologia klejenia jest zaawansowana, w produkcji spotyka się liczne błędy w połączeniach. W praktyce przemysłowej rzadko stosuje się nieniszczące metody oceny. Powszechnie stosowaną metodą kontroli jest destrukcja połączenia i jego wizualna ocena np. ocena ciągłości nałożonej ścieżki kleju. Należy zatem poszukiwać metod, które pozwolą badać stan tego połączenia w sposób nieniszczący.

Metoda ultradźwiękowa umożliwia nie tylko lokalizację ścieżki kleju [1,2], ale pozwala również na oszacowanie siły wiążącej klej z blachą karoseryjną. Przykładowe wyniki

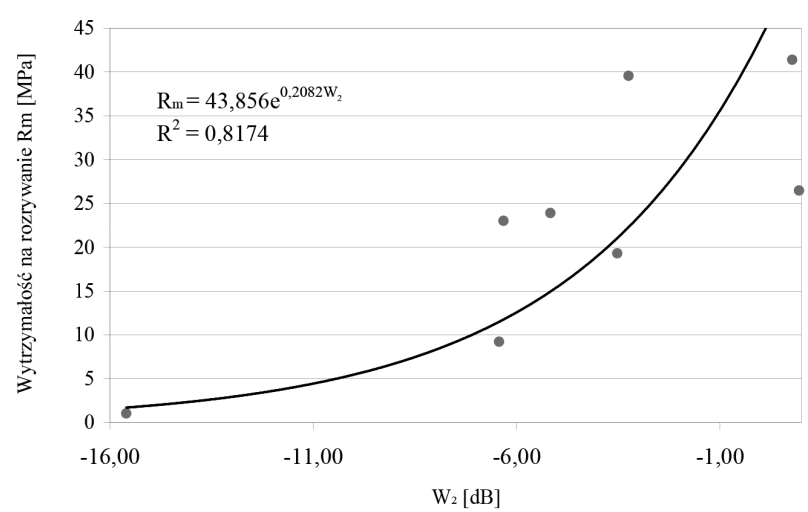

Rys. 1. Zależność między parametrem ultradźwiękowym $\mathrm{W}_{1}$ a wytrzymałością na rozrywanie badanych połączeń $\mathrm{R}_{\mathrm{m}}$

Fig. 1. The relationship between ultrasonic parameter $W_{1}$ and the tensile strength $R_{m}$ of the bonds badań korelacyjnych, w których wyznaczono powiązania wybranych parametrów ultradźwiękowych z naprężeniami rozrywającymi skleinę, przedstawiono na rysunku 1.

Rezultaty przedstawione na rysunku 1 wskazują na istnienie korelacji między przyjętym parametrem fali ultradźwiękowej, a wytrzymałością połączenia na rozrywanie. Można zatem stwierdzić, że metoda ultradźwiękowa umożliwia badanie połączeń klejowych nie tylko z zakresie jakościowym, ale również ilościowym.

\section{Diagnostyka ultradźwiękowa połączenia szpachlówki samochodowej z blachą karoseryjną}

Połączenie szpachlówki samochodowej z blachą karoseryjną znajduje zastosowanie na etapie renowacji karoserii pojazdu samochodowego. Cykl istnienia połączenia powłoki z podłożem można podzielić na okres wytwarzania (kształtowania właściwości połączenia) oraz jego degradacji podczas użytkowania pojazdu, czyli w okresie jego eksploatacji. Istotne jest zatem monitorowanie przedmiotowego połączenia podczas tych dwóch okresów w celu zarówno kontroli jakości podczas jego wytwarzania, jak i przewidywania trwałości w okresie użytkowania.

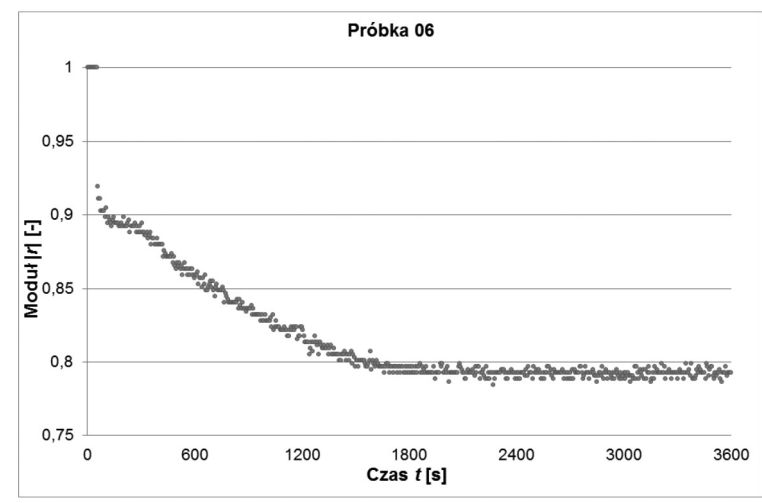

Rys. 2. Przebieg modułu ciśnieniowego współczynnika odbicia $|r|$ fali podłużnej na etapie konstytuowania połączenia powłoki szpachlówkowej z podłożem

Fig. 2. The course of reflection coefficient $|r|$ of ultrasonic longitudinal wave on the stage of constituting of bond of car putty coating and substrate

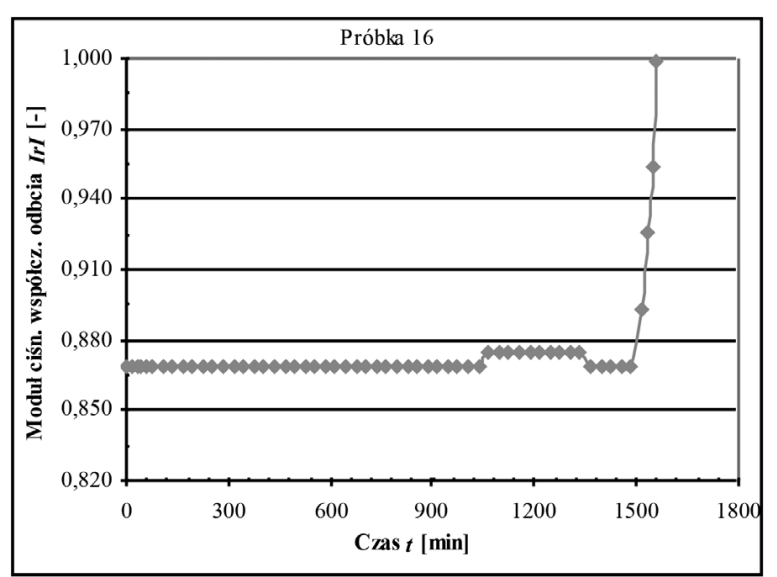

Rys. 3. Przebieg modułu ciśnieniowego współczynnika odbicia $|r|$ fali podłużnej na etapie degradacji połączenia powłoki szpachlówkowej z podłożem

Fig. 3. The course of reflection coefficient |r| of ultrasonic longitudinal wave on the stage of degradation of bond of car putty coating and substrate 
W ramach badań własnych przeprowadzono monitorowanie połączenia szpachlówki ze stalą, z zastosowaniem ultradźwiękowej fali podłużnej, propagującej w materiale podłoża i odbijającej się od granicy połączenia powłoki z podłożem. Na podstawie zmian parametru fali ultradźwiękowej, jakim jest wzmocnienie impulsu, wyznaczono moduł ciśnieniowego współczynnika odbicia $|r|$, odzwierciedlający przyczepność powłoki. Przykładowy przebieg modułu $|r|$ w okresie konstytuowania połączenia powłoki z podłożem, przedstawiono na rysunku 4.1.

W normalnych warunkach eksploatacji, etap degradacji przebiega stosunkowo powoli. W badaniach własnych zatem wykorzystano specjalne stanowisko, które przyspiesza ten proces, wskutek wytwarzania cyklicznych odkształceń badanego połączenia. Szczegóły budowy i działania stanowiska przedstawiono w pracach [3,4], a uzyskane we własnych badaniach wartości modułu ciśnieniowego współczynnika odbicia |r| fali podłużnej podczas okresu degradacji połączenia powłoki z podłożem, przedstawiono na rysunku 4.2.

Wartości modułu ciśnieniowego współczynnik odbicia, uzyskane zarówno w procesie kontytuowania się połączenia (rys. 4.1), jak i w procesie jego degradacji (rys. 4.2) są w ogólnym ujęciu zgodne z przewidywaniami, tzn. zwiększonej wartości przyczepności odpowiadają mniejsze wartości modułu współczynnika odbicia. W szczególności, w fazie konstytuowania połączenia, zmiany wartości parametru dobrze obrazują proces utwardzania szpachlówki po jej nałożeniu na podłoże stalowe.

\section{Ocena przydatności Leptoskopu w badaniach rozkładu grubości powłok lakierniczych}

Do badań i pomiaru grubości powłok lakierniczych użyto PC-Leptoskopu 2050 firmy Karl Deutsch. Powtarzalność a)

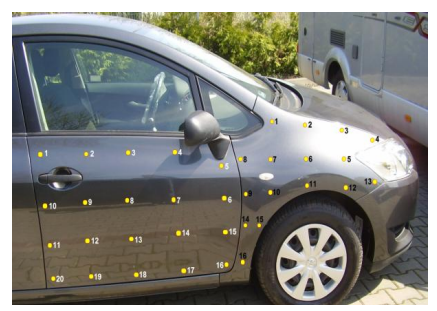

c)
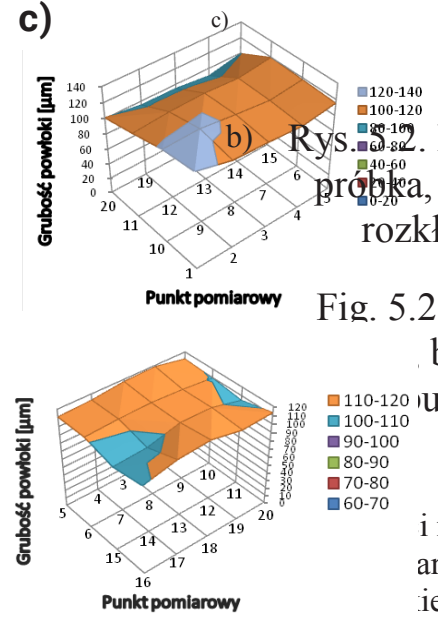

b)

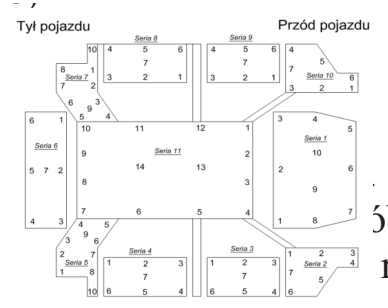

d)
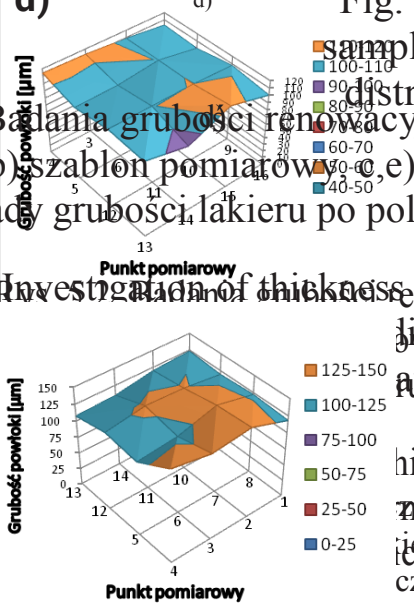

Rys. 4. Badania rozkładu grubości lakieru samochodowego: a) widok samochodu, b) siatka pomiarowa, c) przykładowe rozkłady lakieru fabrycznego, d) przykładowe rozkłady lakieru renowacyjnego Fig. 4. Investigation of thickness of car lacquer: a) view of car, b) measurement web, c) examples of thickness distribution of industrial lacquer, d) examples of distribution of renovative car lacquer pomiarów zapewniono poprzez wykonanie siatki pomiarowej, wyznaczającej punkty pomiarowe na karoserii samochodu oraz poprzez zastosowanie szablonów na próbkach lub wycinkach lakierowanej blachy karoseryjnej [5] (rys. 5.1). Dołączony do przyrządu program statystyczny pozwalał na wyznaczenie podstawowych parametrów statystycznych pomiarów.

Badania rozkładu grubości fabrycznych powłok lakierniczych dla wybranych marek i modeli pojazdów samochodowych uwidoczniły zróżnicowane grubości tych powłok w różnych częściach nadwozia samochodu. Jednocześnie rozrzuty grubości lakieru fabrycznego (rys. 5.1c) są niewielkie w porównaniu z rozrzutami grubości lakierniczej powłoki renowacyjnej (rys. 5.1d), nakładanej w warunkach warsztatowych, podczas napraw bieżących i powypadkowych pojazdów samochodowych.

Niewłaściwe wykonanie renowacyjnych lakierniczych powłok samochodowych (nadmierna grubość, niewłaściwe utwardzanie powłoki oraz polerowanie) może prowadzić do nadpalenia lub spowodować przemieszczania materiału powłoki (rys. 5.2) [5].
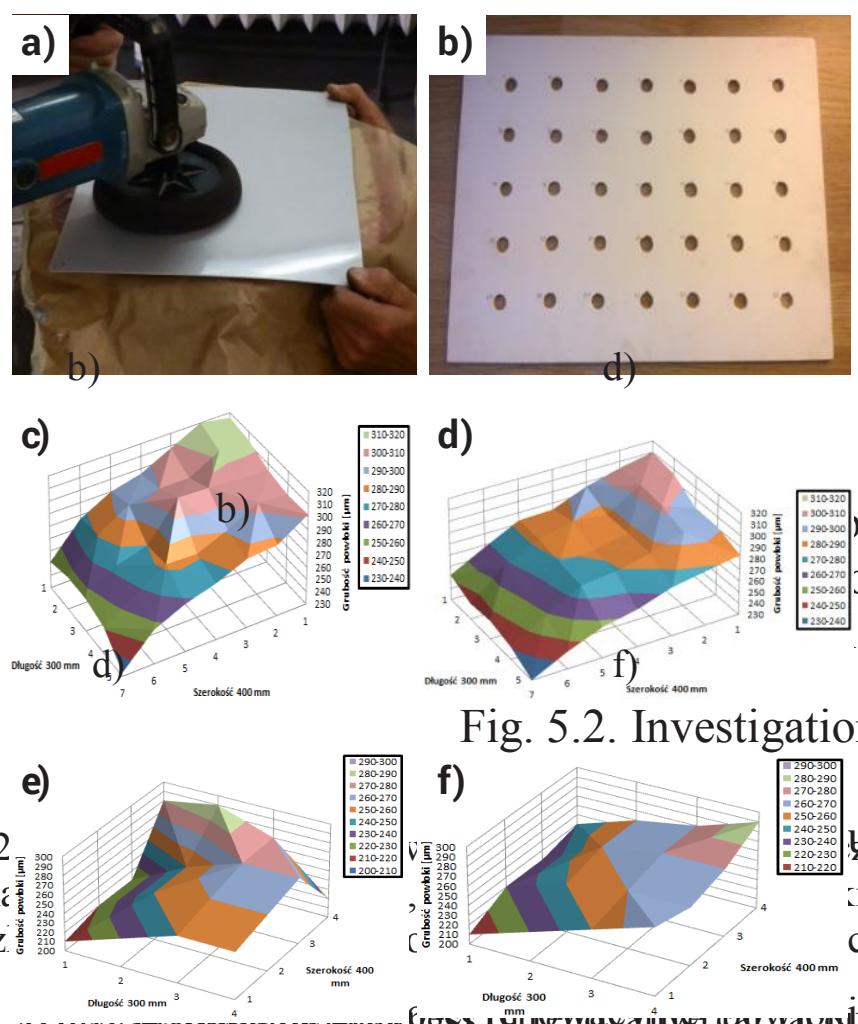

Rys. 5. Badania grubości renowacyjnej powłoki lakierniczej po polerowaniu: a) wybrana próbka, b) szablon pomiarowy, c,e) rozkłady grubości lakieru przed polerowaniem, d,f) rozkłady grubości lakieru po polerowaniu z przemieszczeniem materiału powłoki Fig. 5. Investigation of thickness of renovative car lacquer after polishing: a) selected sample, b) measuring pattern, c,e) distributions of lacquer thickness before polishing, $\mathrm{d}, \mathrm{f}$ ) distributions of lacquer thickness after polishing with displacement material of coating

Polerowanie lakieru samochodu w celu usunięcia rys na lakierze nadwozia nieuchronnie prowadzi do równomiernego ubytku materiału powłoki od kilku do kilkunastu mikrometrów (rys. 5.3) [5].

Także mycie pojazdów samochodowych w myjniach automatycznych lub ręcznych, zwłaszcza w przypadku niestosowania wstępnego spłukiwania kurzu i brudu drogowego, stosowania zużytych szczotek, gąbek, ściereczek, prowadzi do zużycia powłoki lakierniczej, co potwierdziły przeprowadzone badania z zastosowaniem PC-Leptoskopu 2050 (rys. 5.3) [5]. 
a)

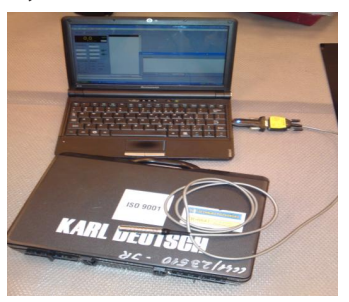

c)

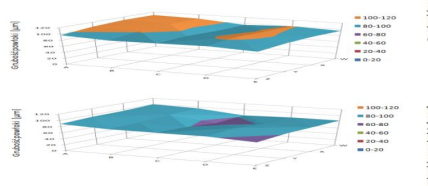

b)

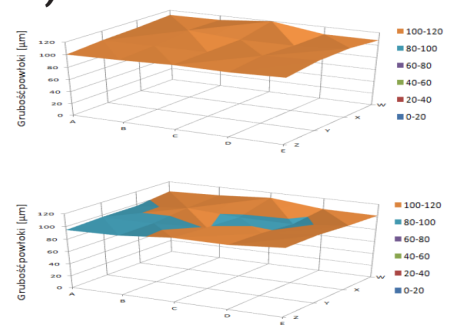

d)
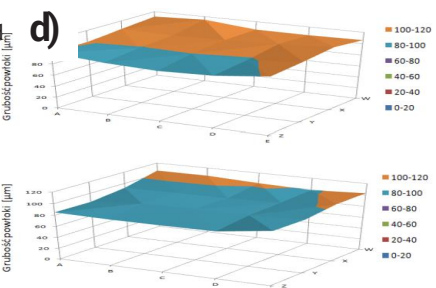

Rys. 6. Pomiar ubytku powłoki lakierniczej samochodu po polerowaniu (wykresy dolne): a) Leptoskop 2050KD, b) polerowanie ręczne, b) ubytek i przemieszczenie materiału powłoki przy temperaturze polerowania $70-80{ }^{\circ} \mathrm{C}$, d) polerowanie mechaniczne Fig. 6. Measurement of removing of car lacquer coating after polishing (bottom diagrams): a) Leptoskop 2050KD, b)hand polishing, b) removing and displacement of material coating at temperature of mechanical polishing $70-80^{\circ} \mathrm{C} d$ ) mechanical polishing

Także mycie pojazdów samochodowych w myjniach automatycznych lub ręcznych, zwłaszcza w przypadku niestosowania wstępnego spłukiwania kurzu i brudu drogowego, stosowania zużytych szczotek, gąbek, ściereczek, prowadzi do zużycia powłoki lakierniczej, co potwierdziły

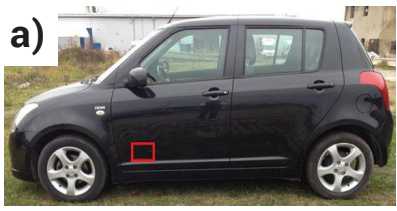

c)

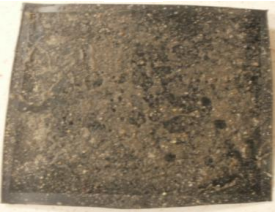

b)

$=$

d)

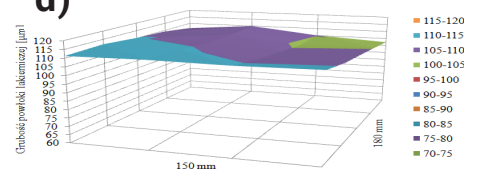

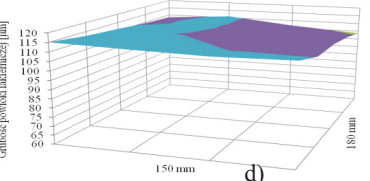

Rys. 6. Badania wpływu mycia na zużycie powłoki lakierniczej: a) widok samochodu z miejscem próbkowania, b) próbka, c) rozkład grubości przed myciem, d) wybrany rozkład grubości lakieru po myciu Fig. 6. Investigation of influence of car washing on lacquer thickness: a) car view with place of sampling, b) a sample, c) thickness distribution of lacquer before washing, d) selected thickness distribution of lacquer thickness after washing

przeprowadzone badania z zastosowaniem PC-Leptoskopu 2050 (rys. 5.3) [5].

Użycie Leptoskopu z sondami jednobiegunowymi, z wykorzystaniem metody elektromagnetycznej i prądów wirowych, umożliwiło wyjaśnienie różnych technologicznych i eksploatacyjnych aspektów nakładania bądź obsługi lakierniczych powłok samochodowych. Pozwoliło na uzyskanie rozkładów grubości powłok lakierniczych, ułatwiających interpretację wyników. Świadczy to o przydatności metody i przyrządu w ocenie grubości powłok lakierniczych.

\section{Podsumowanie}

Zaprezentowane wybrane wyniki badań potwierdzają przydatność stosowanych metod badań nieniszczących w budowie i eksploatacji pojazdów samochodowych. Oprócz dotychczasowego wykrywania nieciągłości strukturalnych części pojazdów samochodowych, możliwe jest użycie metod nieniszczących w badaniu połączeń stosowanych w budowie pojazdów i ich diagnozowaniu podczas eksploatacji. Dzięki tym metodom możliwe jest rozwiązanie problemów kontroli, zarówno istotnych ze względu na sztywność nadwozia węzłów, w tym połączeń zgrzewanych, adhezyjnych i połączeń powłok szpachlówkowo-lakierniczych z blachą karoseryjną, jak i ważnych z punku widzenia jego zabezpieczenia antykorozyjnego.

\section{Literatura}

[1] P. Cawley, J.M. Allin, M.J.S. Lowe, "Adhesive disbond detection of automotive components using first mode ultrasonic resonance" NDT\&E International, Vol. 36, 7, 2003, pp. $503-514$.

[2] J. Kowalczyk, "Assessment of the glue joints in car body by ultrasonic method" Proceedings of 7th European Conference Of Young Research And Science Workers In Transport and Telecommunications, July, 2007.

[3] R. Mańczak, M. Jósko, „Metodyka i stanowisko do badań degradacji połączeń adhezyjnych typu powłoka-podłoże - cz. 1" Journal of Research and Applications in Agricultural Engineering, Vol. 57, 2012, nr 1, s. 105-108.
[4] R. Mańczak, M. Jósko, D. Ulbrich, “Methodology and station for degradation's evaluation of adhesive bonds type coating-substrate. Part 2" Journal of Research and Applications in Agricultural Engineering, Vol. 59, 2014, nr 1, s. 88-93.

[5] Ł. Stefański, W. Dubisz, M. Walczak, N. Dudek, „Opracowania niepublikowane w ramach badań własnych, wykonanych w latach 2010-15" WMRiT PP, Poznań. 